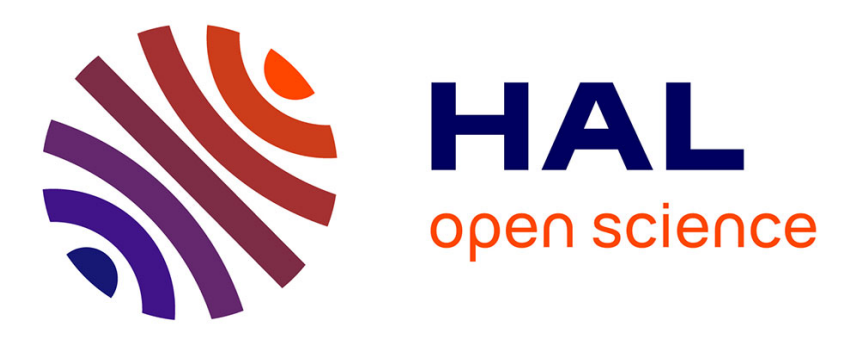

\title{
Characterization of Gas Metal Arc Welding welds obtained with new high Cr-Mo ferritic stainless steel filler wires
}

Vincent Villaret, Frédéric Deschaux-Beaume, Cyril Bordreuil, Gilles Fras, Corinne Chovet, B. Petit, L. Faivre

\section{To cite this version:}

Vincent Villaret, Frédéric Deschaux-Beaume, Cyril Bordreuil, Gilles Fras, Corinne Chovet, et al.. Characterization of Gas Metal Arc Welding welds obtained with new high Cr-Mo ferritic stainless steel filler wires. Materials \& Design, 2013, 51, pp.474-483. 10.1016/j.matdes.2013.04.054 . hal00825148

\section{HAL Id: hal-00825148 \\ https://hal.science/hal-00825148}

Submitted on 23 May 2013

HAL is a multi-disciplinary open access archive for the deposit and dissemination of scientific research documents, whether they are published or not. The documents may come from teaching and research institutions in France or abroad, or from public or private research centers.
L'archive ouverte pluridisciplinaire HAL, est destinée au dépôt et à la diffusion de documents scientifiques de niveau recherche, publiés ou non, émanant des établissements d'enseignement et de recherche français ou étrangers, des laboratoires publics ou privés. 


\title{
Characterization of Gas Metal Arc Welding welds obtained with new high Cr-Mo ferritic stainless steel filler wires
}

\author{
V. Villaret ${ }^{1,2}$, F. Deschaux-Beaume ${ }^{1}$, C. Bordreuil ${ }^{1}$, G. Fras $^{1}$, C. Chovet $^{2}$, B. Petit $^{3}$, L. \\ Faivre $^{3}$ \\ ${ }^{1}$ Université Montpellier II, Mechanical and Civil Engineering Laboratory, 30907 Nîmes, \\ France.
}

${ }^{2}$ Air Liquide, 95310 Saint Ouen l'Aumône, France

${ }^{3}$ APERAM, 62330 Isbergues, France

* Corresponding author. Tel: +33 466628586.

E-mail address: frederic.deschaux-beaume@univ-montp2.fr

\begin{abstract}
Several compositions of metal cored filler wire were manufactured to define the best welding conditions for homogeneous welding, by Gas Metal Arc Welding (GMAW) process, of a modified AISI 444 ferritic stainless steel dedicated to automotive exhaust manifold applications. The patented grade is know under APERAM trade name K44X and has been developed to present improved high temperature fatigue properties. All filler wires investigated contained $19 \% \mathrm{Cr}$ and $1.8 \% \mathrm{Mo}$, equivalent to the base metal $\mathrm{K} 44 \mathrm{X}$ chemistry, but various titanium and niobium contents.

Chemical analyses and microstructural observations of fusion zones revealed the need of a minimum Ti content of $0.15 \%$ to obtain a completely equiaxed grain structure. This structure conferred on the fusion zone a good ductility even in the as-welded state at room temperature. Unfortunately, titanium additions decreased the oxidation resistance at $950^{\circ} \mathrm{C}$ if no significant $\mathrm{Nb}$ complementary alloying was made. The combined high $\mathrm{Ti}$ and $\mathrm{Nb}$ additions made it possible to obtain for the welded structure, after optimized heat treatment, high temperature tensile strengths and ductility for the fusion zones and assemblies, rather close to those of the base metal. $950^{\circ} \mathrm{C}$ aging heat treatment was necessary to restore significantly the ductility of the as welded structure. Both fusion zone and base metal presented rather homogenized properties.

Finally, with the optimized composition of the cored filler wire $-0.3 \mathrm{Ti}$ minimum (i.e. $0.15 \%$ in the fusion zone) and high $\mathrm{Nb}$ complementary additions, the properties, including the thermal fatigue strength, of the K44X assemblies are excellent.
\end{abstract}

Keywords: ferritic stainless steel, welding, oxidation, tensile test, thermal fatigue.

\section{Introduction}

The constant evolution of European anti-pollution standards obliges automotive manufacturers to adapt their new vehicles by working on the improvement of engine efficiency and on weight reductions. Some of the investigations carried out to reach these objectives concerns the exhaust system, that have to be lighter and more resistant to high temperatures produced by the increase of engine efficiency. The exhaust manifold is a critical part of the exhaust system, because it supports very high temperatures and corrosive atmosphere [1-4]. Traditionally made of cast iron in the form of massive components, manifolds can now be made of stainless steel, using tubes or thin sheets rolled and welded [2]. 
Ferritic stainless steels are well suited for such applications, because they present a good resistance to cyclic oxidation and to thermal fatigue, due to their low thermal expansion coefficient compared to austenitic stainless steels. However, these ferritic stainless steels generally have lower strength and lower resistance to isothermal oxidation and creep at high temperature. In addition, they are sensitive to intergranular corrosion, especially after welding, due to the precipitation at grain boundaries of chromium carbides, creating along the grain boundaries chromium depleted zones more sensitive to corrosion [5]. In order to reduce this sensitization phenomenon, some stabilizing elements like niobium or titanium can be added, to promote the formation of carbides of these elements instead of chromium carbides [6-8].

The addition of a few content of $\mathrm{Nb}$ also improves high temperature strength and creep resistance [9]. At higher contents, $\mathrm{Ti}$ and $\mathrm{Nb}$ can however have a detrimental effect on material properties, so their maximum contents have to be limited [10-12]. During aging at high temperature, niobium can form various compounds like Laves phases or complex carbides that decrease ductility, toughness and high temperature strength [9]. Coalescence of niobium carbides during high temperature aging is also detrimental for toughness and ductility [13]. The use of both $\mathrm{Ti}$ and $\mathrm{Nb}$ to stabilize ferritic stainless steels against intergranular corrosion (bi-stabilization) reduces these detrimental effects [14,15]. Since 1980's, ferritic stainless steel grades were introduced in exhaust systems of upper class vehicles. Grades containing 12\% chromium, low carbon and nitrogen contents as well as $\mathrm{Nb}$ stabilizer additions (AISI 409 grade) were developed for such applications [16]. They suffer low oxidation resistance above $900^{\circ} \mathrm{C}$. Grades containing higher chromium content (AISI 430) have better resistance to high temperature oxidation, but can form martensite after heat treatment, even with moderate cooling. Finally, grades containing $18 \% \mathrm{Cr}$ and $2 \% \mathrm{Mo}$ (AISI 444) were more recently developed [17]. The addition of molybdenum has a positive effect on the resistance to cyclic oxidation and simultaneously improve the high temperature strength $[17,18]$. On the contrary, high Mo content has a negative effect on transition temperature, room temperature ductility and toughness. The Mo content consequently has to be limited to about 2\%. [10-11,19-20].

The welding of exhaust systems, generally using a Gas Metal Arc Welding (GMAW) process, can change the materials characteristics. The local heating and rapid cooling induced by welding create a "Heat Affected Zone" (HAZ) around the fusion zone, presenting microstructure changes [21]. In ferritic stainless steels, a sensitization phenomenon can occur in the HAZ, even if $\mathrm{Ti}$ or $\mathrm{Nb}$ stabilizing elements are added [22,23]. Titanium or niobium carbides can be partially dissolved at high temperature, leading during rapid cooling to the precipitation of chromium carbides, thermodynamically less stable but kinetically more favorable, and consequently to the formation of depleted chromium zones in the vicinity of the precipitates [24]. Apparition of some phases as Laves or sigma phases can also decrease the corrosion resistance of ferritic stainless steels [25]. One other issue encountered during welding of ferritic stainless steels is the grain growth in the HAZ, due to the absence of allotropic transformation [27], which has a detrimental effect on the toughness and fatigue resistance. Titanium nitrides are very stable and can improve the resistance to grain growth in the HAZ [26].

The fusion zone obtained during welding can also be affected by these transformations, but some specific phenomena are also observed. First, compositions of base metal and fusion zone can be rather different, due to the dilution of the base metal with a filler metal, required for GMAW process. The molten metal also interacts with environment gas, changing its composition. Contents of $\mathrm{C}$ and $\mathrm{N}$ gamma stabilizer are for instance generally higher in the welding zone due to gas interaction, promoting the formation of gamma phase at high temperature and martensite after rapid cooling [27]. On high chromium ferritic grades or 
stabilized ferritic grades however, martensite is not observed in molten zone. In addition, grain size and morphology can be very different in the fusion zone. Grains in this zone often have a large columnar morphology, due to the solidification mechanism in a thermal gradient, that confers poor properties in terms of ductility, toughness and fatigue strength, but also a risk of intergranular corrosion [28,29]. A finer equiaxed grain structure can be obtained in some specific conditions [30-33]. The transition between columnar to equiaxed grains (CET) is promoted by the constitutional undercooling in the weld pool just in front of the columnar solidification front [27-28], that depends mainly on the steel composition and welding parameters, and by the addition of some elements favoring the heterogeneous nucleation of new grains in the undercooling zone. Titanium is a particular element that forms complex refractory compounds in the weld pool, giving nucleation sites for equiaxed grains [27,34-36]. Aluminum also in some conditions promotes the CET, with the formation of $\mathrm{Al}_{2} \mathrm{O}_{3}$ particles in the weld pool before solidification of the alloy [37-38]. However the particles formed in the weld pool can also have a detrimental effect on the mechanical properties, especially if their size is large.

In this paper, new filler wires for GMAW process developed to weld AISI 444 modified grades for gas collector applications are tested. The base material, developed by APERAM for such application, contains high $\mathrm{Cr}$ and Mo additions, but there is no currently filler wire allowing a homogeneous welding, i.e. filler metal containing about the same contents of alloying elements. The composition, microstructure, oxidation resistance and high temperature mechanical strength of the fusion zones obtained are investigated. High temperature tensile tests and thermal fatigue tests on assemblies are also achieved and the results are discussed with respect to the requirements of the application.

\section{Experimental details}

\subsection{Base metal}

The base material used in this study is a new ferritic stainless steel developed by APERAM to manufacture exhaust systems, and more generally for uses at high temperature under mechanical loading and corrosive atmosphere. Its composition corresponds to a modified AISI 444 grade according to the American Standard AISI, and it is called by the commercial name K44X. With a chromium content of $19 \%$ and the addition of molybdenum (table 1), it has an oxidation resistance at high temperature better than the classical AISI 444 grade and of course presents significantly better behavior than standard AISI 430 steels as well as that of austenitic stainless steels like AISI 304 grade.

The steel is mono-stabilized - no titanium - and consequently contains a rather high content of niobium to prevent sensitization issues after welding. The reason of the mono-stabilization is given by the formation with this element of intermetallic phase $\mathrm{Fe}_{2} \mathrm{Nb}_{3}$, more stable at high temperature, that highly improve the creep strength and fatigue resistance of the material at high temperatures. The $\mathrm{Fe}_{2} \mathrm{Nb}_{3}$ precipitates furthermore control the ferritic grain growth in the HAZ of welds.

\subsection{Welding process}

A GMAW process using a DIGIWAVE® generator is used for welding K44X base material with various filler metals. The welding gas is a mixture of Ar with $2 \% \mathrm{CO}_{2}$ (AIR LIQUIDE ARCAL 12), usually used for welding stainless steels in automotive industry. Two sets of welding parameters are determined for each filler metal, corresponding to different transfer modes, pulsed or short-circuit. To have a good transfer, electrical parameters (voltage and intensity) are adjusted for each composition of filler metal, so the electric power is slightly 
different for each one. However, for each filler metal, the electric power and the welding speed are always higher in pulsed mode than in short-circuit mode. The welded samples obtained in short-circuit mode always show a bad wetting of the fusion zone, which is not suited to support cyclic loading [39]. For this reason, only the welded samples obtained in pulsed mode with various filler metals are characterized in this paper. The welding results obtained in short-circuit mode are available in [39]. The welding parameters used in pulsed mode are given on table 2 . The welding tests consist in linear weld deposits in the longitudinal direction of $2.3 \mathrm{~mm}$ thick, $120 \mathrm{~mm}$ wide and $400 \mathrm{~mm}$ long sheet samples of base metal.

\subsection{Filler metals}

In order to investigate the influence of filler metal composition on the weld properties, seven filler wires with different chemical compositions have been developed. All the filler wires have the same $\mathrm{Cr}$ and Mo contents as the base material (19\% and 1.9\% respectively), but various $\mathrm{Ti}$ and $\mathrm{Nb}$ contents, to promote the CET and improve high temperature behavior. To allow an easy change of chemical composition of filler metals, a "Chemetron" manufacturing process is chosen for making metal cored filler wires (US Patent $\mathrm{n}^{\circ} 4282420$, 1981). This kind of filler wire is well suited because the additional elements can be introduced as powder mixture in the core. The external foil is an AISI 409 stainless steel, containing 12\% $\mathrm{Cr}$ and $0.2 \% \mathrm{Ti}$ (Table 3). $\mathrm{Cr}, \mathrm{Mo}, \mathrm{Nb}$ and $\mathrm{Ti}$ additional contents are then adjusted in the powder mixture of the core, to obtain the desired composition in the deposited metal. All details concerning the manufacturing process of metal cored filler wires are given in [39]. The global compositions, including elements in the foil and in the core powder, of the seven metal cored filler wires manufactured for this study are given on table 3 . The various filler wires (FW) are numbered from 2 to 8 , and the welded samples (WS) and fusion zones (FZ) obtained are numbered in the same way.

\subsection{Characterization methods}

\subsubsection{Chemical and microstructural analyses}

In order to investigate the relation between chemical composition and microstructure of the fusion zones, the welded samples are prepared for metallographic observations and chemical analyses.

A small volume (about $100 \mathrm{~mm}^{3}$ ) of fusion zones obtained with each filler wire is mechanically extracted, and its chemical composition is determined using a Horiba Jobin Yvon JY238 Inductive Coupled Plasma (ICP) system.

Cross sections of welded samples are cut, polished up to grade $4000 \mathrm{SiC}$ paper, and prepared with Marble reactant $\left(4 \mathrm{~g} \mathrm{CuSO}_{4}-20 \mathrm{ml} \mathrm{HCl}-20 \mathrm{ml} \mathrm{H}_{2} \mathrm{O}\right)$. The structures of the fusion zones are investigated using a LEICA Z16 APO system for the macro-scale, and an optical microscope LEICA DMI5000M for the micro-scale.

\subsubsection{Oxidation tests}

To compare the oxidation behavior of the fusion zones and the base metal, isothermal oxidation tests in air are achieved on samples extracted from as received sheets of base metal and from the welds. Samples are heated in a furnace at $950^{\circ} \mathrm{C}$ during 100,200 and $370 \mathrm{~h}$, and mass changes induced by the oxidation phenomenon are measured. 3 similar samples are tested for each condition. After these first mass measurements, oxidized samples are submitted to a "conditioning" treatment consisting in an etching of the sample surface with a $\mathrm{NaOH} / \mathrm{KMnO}_{4}$ solution at $100^{\circ} \mathrm{C}$ during 24 hours, to dissolve all the adhesive oxide. The mass loss after conditioning is measured, allowing determining the quantity of oxidized metal. Oxidation tests are carried out according to the ISO 21608 standard [40], except for the 
sample geometry. For the oxidation tests on welds, the surface of the fusion zone is in the aswelded state.

Due to the low width of the fusion zones obtained (less than $2 \mathrm{~mm}$ on the back side), oxidation tests on welds are carried out on heterogeneous samples, containing both fusion zone and base material (Fig. 1a). To allow comparisons between the oxidation behavior of fusion zones and base metal, external surfaces of the samples were scanned before oxidation tests using a 3D OPTO TOP-HE BREUCKMANN apparatus. The digitized surfaces are then decomposed in two parts, corresponding to the external surfaces of fusion zone and base metal.

\subsubsection{Tensile tests}

To characterize the mechanical behavior of the fusion zones, special tensile sample geometries have to be defined. The small size of the fusion zones requires to use specimens with reduced width, and non standardized geometries. The chosen geometry is given on Fig. 1b. The calibrated samples section is approximately $1.45 \times 1.9 \mathrm{~mm}^{2}$. An INSTRON J5362 tensile machine is used, with a force cell of $10 \mathrm{kN}$.

Tensile tests are carried out at room temperature, $850^{\circ} \mathrm{C}$ and $950^{\circ} \mathrm{C}$. For the high temperature tensile tests, heating of tensile samples is achieved using a 3 zones resistance furnace, at the heating rate of $10^{\circ} \mathrm{C} / \mathrm{min}$. A dwell time of 10 minutes at the test temperature is respected before each test. Some samples were aged before testing during 50 to $100 \mathrm{~h}$ at $950^{\circ} \mathrm{C}$. The strain is measured using an EPSILON MODEL 3548Hi extensometer, with a gauge length of $25 \mathrm{~mm}$. Tensile tests are achieved with a strain rate of $0.005 \mathrm{~min}^{-1}$ up to $0.45 \%$ strain, and $0.02 \mathrm{~min}^{-1}$ after this strain value.

In order to investigate the mechanical behavior of the assemblies, some tensile tests are achieved on samples of $12.5 \mathrm{~mm}$ wide and $1.45 \mathrm{~mm}$ thick, cut transversally to the welding direction. Transverse tensile tests are carried out at $950^{\circ} \mathrm{C}$, with the same strain rates than for tensile tests on fusion zone, according to the EN ISO 6892-2 standard [41]. For each test condition, two similar tensile samples are tested.

\subsubsection{Thermal fatigue tests}

The thermal fatigue tests are achieved using a dedicated test developed by APERAM [3]. The sample consists of a $200 \mathrm{~mm}$ long and $20 \mathrm{~mm}$ wide "strip" cut transversally to the weld seam, formed to a V shape, and fixed between two jaws (Fig. 2a). The HAZ of the weld is placed at the center of the fold at the top of the sample. The specimen is heated by Joule effect thanks to a high current supplied by a regulated power transformer. The specimen temperature is controlled thanks to a $\mathrm{K}$ type thermocouple welded on the external face of the fold.

The thermal fatigue test consists in heating up and cooling down a fold sample between two fixed jaws in air repeatedly between $250^{\circ} \mathrm{C}$ and $950^{\circ} \mathrm{C}$. During each cycle, the maximal load in the jaws is measured thanks to a force sensor. During heating, the specimen is subjected to a compressive loading generated by the thermal expansion, inducing a tensile stress on the outer part of the fold (and a compressive stress on the inner part). At the opposite, during the cooling, the base of the specimen is in a tensile state, inducing a compressive stress in the outer part of the fold, and a tensile stress on the inner part (Fig. 2b). The test is stopped when the load measured at the jaws falls down under $50 \%$.

\section{Results and discussion}

\subsection{Composition and microstructure of the fusion zones}

The composition of the fusion zones obtained with the different filler wires, measured by ICP, are given in table 4. The $\mathrm{Cr}$ and Mo contents have not been measured in all samples, because 
their contents are about the same in all the filler wires and the base metal (19\% and 1.9\% respectively), so one can expect the same contents whatever the filler wire used. Analysis of Cr content in fusion zones 2 and 5 shows a content a little bit higher but very closed to those expected. The Mo content in fusion zones 3 and 6 corresponds to the expected values. These results confirm the good transfer of chromium and molybdenum during the arc melting of the filler wires, which was previously observed [39]. The contents of the other elements are rather similar in all fusion zones, except for titanium and niobium, due to the large differences of these elements in the various filler wires.

The structure of the various fusion zones are also very different (Fig. 3). When the fusion zone contains a low content of titanium, grains are large and columnar. At the opposite, for high Ti content in the fusion zone, grains are finer and equiaxed. One can see in Fig. 3 the transition from a columnar grain structure to an equiaxed grain structure appearing for $\mathrm{Ti}$ content between 0.1 and $0.15 \%$. Below $0.1 \% \mathrm{Ti}$ in the fusion zone $(\mathrm{FZ2}, 4,5,7)$, the grain structure is completely columnar (Fig. 3a). With about $0.1 \%$ titanium (FZ6), the grains are mainly columnar, with only a small fraction of equiaxed grains on the top of the weld pool (Fig. 3b). Finally, with $0.15 \% \mathrm{Ti}$ (FZ8), grains in the fusion zone are completely equiaxed (Fig. 3c). A further increase of the Ti content in the fusion zone (FZ3) does not improve the structure, as shown in Fig. 3d, indicating the grains have similar morphology and size with $0.25 \% \mathrm{Ti}$ as with $0.15 \%$. The observation of the microstructure of the fusion zones with scanning electron microscope and energy-dispersive spectroscopy presented in a previous paper [39] revealed very fine titanium rich particles uniformly dispersed. Samples richer in Ti contained more titanium precipitates. These results are in agreement with literature data indicating that Ti promotes the CET by forming refractory compounds in the weld pool before the solidification of steel, creating heterogeneous nucleation sites [34-36]. However, the nature of the refractory compounds, as well as the nucleation mechanism are not currently elucidated. The effect of titanium is not the same as it is introduced as oxide or metal as well as alone or combined with other metals during welding [35,38].

Niobium seems to have no effect on the grain structure of the fusion zone. This element is added only to improve high temperature properties. In all cases, the base metal seems to be not much affected by the welding process, confirming the good thermal stability of this steel under rapid thermal cycles. Indeed the HAZ is composed by moderate grown grains (grain size $<100 \mu \mathrm{m})$.

\subsection{Oxidation tests results}

The evolution of the mass variation during isothermal oxidation before conditioning for the base material and the various welded samples is shown in Fig. 4. One can observe rather different behaviors. The base material shows a mass gain with a parabolic evolution, indicating a typical oxidation kinetic diffusion controlled [42]. At the opposite, the welded samples show mass losses, traducing the spallation of the oxide layer. This phenomenon is particularly observed in welded sample 3 , the richest in $\mathrm{Ti}$.

The evolution of the mass loss after the conditioning treatment for various welded samples is compared to the base metal one in Fig. 5a. Except for the weld 6, showing an oxidation behavior very closed to the base metal, the oxidation rates are higher for the welded samples. Fig. 5a shows raw results of oxidation tests, and gives the average values of the mass loss per unit area of the samples. In welded samples, the global mass loss measured is the addition of the mass losses of the base metal and of the fusion zone. The surface of the fusion zone has been measured on each welded sample thanks to the digitization of samples surface (see section 2.4.2). Using these measures, it is possible to deduce the mass loss per unit area for the fusion zone only from the results of oxidation tests on welded samples, supposing the base 
metal in welded samples is oxidized at the same rate than in homogeneous base metal samples.

Fig. $5 \mathrm{~b}$ shows the comparison between the mass losses of the fusion zone and base metal.

Trends observed on the average values are amplified, and one can see the fusion zone 3 has a mass loss higher than $180 \%$ of the base metal one after $370 \mathrm{~h}$ at $950^{\circ} \mathrm{C}$.

The oxidation rate seems to be related to the Ti content in the fusion zone. Fig. 6 shows the evolution of the mass loss versus Ti content, deduced from Fig. $5 \mathrm{~b}$ and table 4. One can clearly see an increase of the oxidation rate with the Ti content.

The spallation of an oxide layer is enhanced by the increase of its thickness, which increases stresses induced by volume changes due to oxidation. Some elements can also promote the spallation, by creating brittle compounds between the metal and the oxide layer, and decreasing the adhesion energy [43]. The comparison of the mass change of samples before and after conditioning, allow to estimate the quantity of "adhesive oxide", that is an indication of the adhesion energy. Indeed, if one consider the formed oxide is similar for each case, the thicker is the oxide layer, the higher is the adhesion energy.

Fig. 7a shows the evolution of the mass of adhesive oxide. The maximum mass of adhesive oxide is lower for the fusion zones, especially for number 6 and 3, than for the base metal, indicating a possible lower adhesion energy of the oxide layer.

Thanks to the comparison between the mass loss after conditioning, indicating the total mass of oxidized metal, and the mass change before conditioning, indicating the mass of adhesive oxide, it is also possible to estimate the quantity of spalled oxide for each sample. The total mass loss after conditioning corresponds to the mass of oxidized metal, present in the adhesive oxide and in the oxide layer eliminated by spallation.

Considering the oxide is mainly chromium oxide, which is generally admitted for such steel composition despite of some minor oxides formed [43], the quantity of spalled oxide can be estimated according to the relation:

$$
\left(\frac{\Delta \mathrm{m}_{\mathrm{C}_{2} \mathrm{O}_{3}}}{\mathrm{~S}}\right)_{\substack{\mathrm{s} \\ \mathrm{p}}}=\left(\frac{\Delta \mathrm{m}_{\mathrm{C}_{2} \mathrm{O}_{3}}}{\mathrm{~S}}\right)_{\substack{\mathrm{t} \\ \mathrm{t}}}-\left(\frac{\Delta \mathrm{m}_{\mathrm{C}_{2} \mathrm{O}_{3}}}{\mathrm{~S}}\right)_{\substack{\mathrm{a} \\ \mathrm{d}}}=\frac{2 \mathrm{M}_{\mathrm{C}}+3 \mathrm{M}_{\mathrm{O}}}{2 \mathrm{M}_{\mathrm{C}}}\left(\frac{\Delta \mathrm{m}_{\mathrm{C}}}{\mathrm{S}^{\mathrm{r}}}\right)_{\substack{\mathrm{t} \\ \mathrm{o} \\ \mathrm{t}}}-\left(\frac{\Delta \mathrm{m}_{\mathrm{C}_{2} \mathrm{O}_{3}}}{\mathrm{~S}}\right)_{\substack{\mathrm{a} \\ \mathrm{d}}}
$$

where $M_{C r}$ and $M_{O}$ are the molar mass of $C r$ and $O$ respectively, $\left(\frac{\Delta m_{C}}{S^{r}}\right)_{t}$ the total mass loss after conditioning, and $\left(\frac{\Delta \mathrm{m}_{\mathrm{C}_{2} \mathrm{O}_{3}}}{\mathrm{~S}}\right)_{\mathrm{a}}$ the quantity of adhesive oxide, given in Fig. 7a.

Fig. $7 \mathrm{~b}$ shows the results obtained according to relation 1 . One can see that according to this calculation, the base metal is not sensitive to spalling, whereas fusion zone 3 is the most sensitive. This fusion zone also contains the highest Ti content $(0.25 \%)$.

The detrimental effect of Ti on the spallation sensitivity observed in this study is not in agreement with the results obtained by Mougin et al. [43]. These authors observed at the opposite a beneficial effect of $\mathrm{Ti}$, that forms oxides between $\mathrm{Cr}_{2} \mathrm{O}_{3}$ layer and metal favoring the adhesion of the oxide layer. This effect however could be counterbalanced by $\mathrm{Nb}$ that can form brittle intermetallic compounds at the interface between the metal and the oxide layer [43].

In our case, it is possible that complex interactions take place between $\mathrm{Nb}$ and $\mathrm{Ti}$, and influence the resistance to spallation of the oxide layer. Indeed, fusion zone 6 seems more sensitive to spallation than fusion zone 8 , but contains less titanium, that is in opposition to that observed for other compositions. However, fusion zone 6 also contains a lower niobium 
content. The spallation sensitivity seems to increase with the $\mathrm{Ti} / \mathrm{Nb}$ ratio, confirming the possible interaction between these elements (Fig. 8).

The increase of the spallation sensitivity could partially explain the higher oxidation rate of the fusion zones containing high Ti content, the spallation of the oxide layer promoting the oxidation because the metal is unprotected. However, this is probably not the only explanation, because fusion zone 8 shows a higher oxidation rate than fusion zone 6 , but is less sensitive to spallation.

\subsection{Mechanical behavior of the welds}

It is generally accepted that in as-welded fusion zones, a coarse columnar grains structure do not exhibit good mechanical properties at room temperature, especially concerning ductility. A simple test consisting in a bending at room temperature of a strip cut in the transverse direction of welded samples would only reveal that one with equiaxed grain structure in the fusion zone allow a complete $180^{\circ}$ bending without cracking. At the opposite, samples with columnar grain structure in the fusion zone would be cracked in the weld centerline after the $180^{\circ}$ bending test.

The intended application, i.e. the manufacture of exhaust manifolds, requires the ability of welded samples to support cold forming, by rolling or bending. For this reason, only the fusion lines obtained with filler wires containing high Ti contents (upper to $0.1 \%$ in the FZ, i.e. FW 8 and 3), showing an equiaxed grain structure, are suited for the application.

Fig. 9 shows the room temperature behavior of the base metal and the fusion zone 8, obtained from longitudinal tensile tests achieved on small samples machined in the fusion zone (Fig. 1b). Despite its equiaxed grain structure, the as-welded fusion zone 8 shows a rather low ductility compared to the base metal. This could be due to segregation phenomenon during solidification, which can promote the formation of brittle compounds in the intergranular spaces. An aging treatment during $100 \mathrm{~h}$ at $950^{\circ} \mathrm{C}$ improves the ductility, which however remains lower than the base metal. In service, aging supported by exhaust manifold might then improve the ductility of such welds. The ultimate strength at room temperature is sensibly equivalent to the base metal, and is not changed after aging.

At high temperature, the mechanical properties of ferritic stainless steels are dependant on the niobium content [9]. To evaluate the effect of $\mathrm{Nb}$, tensile tests are carried out at $850^{\circ} \mathrm{C}$ on two fusion zones with $\mathrm{Nb}$ contents of 0.2 and $0.5 \%$, and on the base material $(0.6 \% \mathrm{Nb})$.

In the as-welded state, the ultimate strength at high temperature of both fusion zones is slightly higher than the base metal, but with a lower ductility (Fig. 10). However, after aging at $950^{\circ} \mathrm{C}$ during $100 \mathrm{~h}$, the ultimate strength of the fusion zone decreases, maybe due to the homogenization of the segregation zones. The ultimate strength is a little bit lower for fusion zone 2 , containing the lower $\mathrm{Nb}$ content $(0.2 \%)$, which confirms the positive effect of $\mathrm{Nb}$ on the high temperature strength.

Tensile tests at $950^{\circ} \mathrm{C}$ in the fusion zone $8(0.45 \% \mathrm{Nb})$ show about the same results, with a higher strength but a lower ductility than the base metal in the as-welded state, and a decrease of the strength but an increase of the ductility of the fusion zone after aging (Fig. 11).

High temperature transverse tensile tests on as-welded samples confirm the higher strength of the fusion zones, because the failure is always located in the base metal. After aging at $950^{\circ} \mathrm{C}$, the failure is still located in the base metal. The tensile curves shown in Fig. 12 reveal that the base metal exhibits a strength decrease after aging, in the same trend as the fusion zones. The comparison of the behaviors of aged assemblies, where the fracture is located in the base metal, and of aged fusion zones, indicates a homogenization of the behavior of both zones during aging, which reduce stress concentrations in the weld seam and therefore can be beneficial for the fatigue lifetime of assemblies, Despite its lower $\mathrm{Nb}$ content compared to the 
base metal, the fusion zone 8 thus has a good mechanical behavior at $950^{\circ} \mathrm{C}$, coupled to a rather good ductility at room temperature after aging.

\subsection{Fatigue tests}

The aim of these tests is to evaluate the ability of assemblies to resist to thermal cycles representative of those suffered by exhaust manifold. This ability is estimated by comparing thermal fatigue lifetime of welded samples with the lifetime of the base material.

3 specimens were tested for fusion zones 7 and for FZ 8 , and compared to the base material (2 specimens).

Table 5 shows the number of cycles to failure obtained for all the thermal fatigue tests. The lifetime of welded samples is in general shorter, but in the same order, than the one of the base metal. These differences can be explained by geometrical changes between base metal samples and welded samples. The stiffness of the welded samples is different due to the higher thickness of the fusion zone. The thermal fatigue samples are then dissymmetric, and the strains are slightly shifted to the opposite side to the weld in the V sample (Fig. 13). This is confirmed by the thermal expansion forces measured in the jaws, which are higher for the welded samples than for the base material (Fig. 14).

The failure is always located in the base material, close to the fold on the opposite side to the fusion zone (Fig. 15). The main crack is initiated on the inner side of the fold, as for the thermal fatigue tests carried out on the base metal. This zone supports compressive stresses during the heating, and tensile stresses during the cooling of the sample. Cracks are then formed during the cooling of the sample, at lower temperature.

This cracking mechanism is different from that observed on austenitic stainless steels. In that case, cracking appears also on the outer side of the fold, which supports tensile stresses at high temperature, indicating a possible interaction between cracking and oxidation [44]. These results are different from that observed on welded samples obtained with austenitic stainless steel filler wires. In that case, the lifetime can be significantly reduced and the cracks are localized at the interface between the base metal and the fusion zone, probably due to the difference of thermal expansion coefficient that involves accommodation strains at the interface [45].

\section{Conclusion}

Seven new compositions of filler metals were tested to perform welding with GMAW process of a modified AISI 444 ferritic stainless steel for exhaust manifold applications. The fusion zones obtained with the different filler wires had the same chromium and molybdenum contents as the base metal (19\% and $1.9 \%$ respectively), but various $\mathrm{Ti}(0.04$ to $0.25 \%)$ and $\mathrm{Nb}(0.1$ to $0.7 \%)$ contents.

The grain structure in the fusion zone was completely columnar for low Ti contents, or finer and equiaxed when the Ti content was above $0.15 \%$. The equiaxed microstructure presented improved properties when cold forming, and drawability was enhanced.

The oxidation rate of the fusion zones increased with higher Ti content. Complementary $\mathrm{Nb}$ additions decreased sharply this negative effect. The resistance to spallation seemed to be significantly improved when the niobium content was high.

The ductility at room temperature of equiaxed fusion zones (containing $0.15 \% \mathrm{Ti}$ ) in the aswelded conditions was weaker but sufficient to accept some cold forming. An aging heat treatment at $950^{\circ} \mathrm{C}$ increased significantly the ductility.

At high temperature, the strength of as-welded fusion zones was slightly higher than the base metal, but decreased after aging at $950^{\circ} \mathrm{C}$. The increase of the $\mathrm{Nb}$ content in the fusion zone had only a weak effect on the improvement of the high temperature strength. 
Finally, thermal fatigue tests confirmed the ability of the assemblies to support thermal cycles encountered in real exhaust life. The number of cycles to failure of the assemblies was somewhat lower than the base metal samples, but acceptable for in service applications. An increase of the sample stiffness due to the higher thickness of the welds was observed and could explain the decrease of the number of cycles to failure. The failure mechanism was the same as that observed in the base metal. Finally cycles to failure was significantly enhanced compared to the $\mathrm{K} 44 \mathrm{X}$ grade welded with austenitic filler wires.

\section{Acknowledgements}

The authors wish to thank Air Liquide, Saint-Ouen l'Aumône for manufacturing the filler wires and for its financial support for this study, Joel Claeys and Pierre-Olivier Santacreu, from APERAM , Isbergues, for supplying the K44X steel, and for their help for material characterization.

\section{References}

[1] Schwartz R. A ferritic welding grade for exhaust applications. IIW International Congress, Stellenbosch, South Africa, 8-10 March 2006.

[2] Santacreu PO, Cleizergues O, Simon C, Duroux P. Design of stainless steel automotive exhaust manifolds. Revue de Métallurgie 2004; 101: 615-620

[3] Santacreu PO, Bucher L, Koster A, Remy L. Thermomechanical fatigue of stainless steels for automotive exhaust systems. Revue de Métallurgie 2006; 103: 37-42.

[4] Santacreu PO, Saedlou S, Faivre L, Acher A, Leseux J, Ferritic Stainless Steel Grade with Improved Durability for High Temperature Exhaust Manifold. SAE World Congress; Detroit, Michigan, United States; 12 April 2011.

[5] Pickering FB. Physical Metallurgy and the Design of Steels. Applied Science Publishers LTD, London; 1978.

[6] Gates JD, Jago RA. Effect of nitrogen contamination on intergranular corrosion of stabilized ferritic stainless steels. Mater Sci Technol 1987; 3: 450-454.

[7] Dundas HJ, Bond AP. Niobium and titanium requirements for stabilization of ferritic stainless steels. ASTM STP, RF Steigerwald Ed. 1978; 656: 154-178.

[8] Gordon W, Van Bennekom A. Review of stabilisation of ferritic stainless steels. Mater Sc Technol 1996; 12: 126-131.

[9] Fujita N, Ohmura K, Yamamoto A. Changes of microstructures and high temperature properties during high temperature service of niobium added ferritic stainless steels. Mater Sc Engineer 2003; A351: 272-281.

[10] Semchyshen M, Bond AP, Dundas HJ. Effects of composition on ductility and toughness of ferritic stainless steels. Proceedings of the symposium Toward Improved Ductility and Toughness, Kyoto, Japan,oct 25-26, 1971, p. 239-253. 
[11] Steigerwald RF, Dundas HJ, Redmond JD, Davison RM. The physical metallurgy of FeCr-Mo ferritic stainless steels. Metall. Mater. Technol 1978; 10: 181-189.

[12] Van Zwieten ACTM, Bulloch JH. Some considerations on the toughness properties of ferritic stainless steels - a brief review. Int J Press Vessels Piping 1993; 56: 1-31.

[13] Sim GM, Ahn JC, Hong SC, Lee KJ, Lee KS. Effect of Nb precipitate coarsening on the high temperature strength in $\mathrm{Nb}$ containing ferritic stainless steels. Mater Sc Engineer 2005; A396: 159-165.

[14] Wang LX, Song CJ, Sun FM, Li LJ, Zhai QJ. Microstructure and mechanical properties of 12 wt.\% Cr ferritic stainless steel with $\mathrm{Ti}$ and $\mathrm{Nb}$ dual stabilization. Mater Des 2008; 30: 49-56.

[15] Yan H, Bi H, Li X, Xu Z. Microstructure and texture of Nb+Ti stabilized ferritic stainless steel. Mater Charact 2008; 59: 1741-1746.

[16] Li HB, You XM, Jiang ZH. Ultra-pure ferritic stainless steels grade, refining operation, application. Journal of Iron and Steel Research 2007; 4: 24-30.

[17] Miyasaki A, Hirasawa J, Furukimi O. Development of high heat-resistant ferritic stainless steel with high formability, "RMH-1", for automotive exhaust manifolds by optimizing Mo composition design. Kawasaki Steel Technical Report 2003; 48: 28-32.

[18] Sephton M, Nkosi ZW, Potgieter JH. Corrosion of hot end automotive exhaust components. Anti-Corrosion Methods and Materials 2007; 54(3): 180-187.

[19] Bond AP, Sawhill Jr JM. Ductility and toughness of stainless steel welds. Weld J 1976; 55: $33 \mathrm{~s}-41 \mathrm{~s}$.

[20] Meyer HW, Steigerwald RF, Jarleborg O. Nouvel acier inoxydable ferritique à $18 \% \mathrm{Cr}$ et $2 \%$ Mo. Mater Tech 1974; 62: 147-155.

[21] Xinzhong L, Jingtuo H, Wanhua Y, Shifeng D. Structure change of 430 stainless steel in the heating process. Journal of University of Science and Technology Beijing, Mineral, Metallurgy, Material 2008; 15: 34-37.

[22] Du Toit M, Van Rooyen GT, Smith D. An overview of the heat-affected zone sensitization and stress corrosion cracking behavior of $12 \%$ chromium type 1.4003 ferritic stainless steel. IIW Doc IX-H-640, 2006.

[23] Greeff ML, Du Toit M. Looking at the sensitization of 11-12\% chromium EN 1.4003 stainless steels during welding. Weld J 2006; 85: 243s-251s.

[24] Van Warmelo M, Nolan D, Norrish J. Mitigation of sensitisation effects in unstabilised $12 \%$ Cr ferritic stainless steel welds. Mater Sc Engineer 2007; A464: 157-169.

[25] Silva CC, Farias JP. Microstructural characterization of the HAZ in AISI 444 ferritic stainless steel welds. Mater Character 2008; 59: 528-533. 
[26] De Azevedo Silva L, Iglesias Lourenço Lima L, Reis Da Costa Campos W.

Microstructural characterization of the HAZ of the AISI 439 with different heat input.

International Nuclear Atlantic Conference - INAC 2007, Santos, SP, Brazil, September 30 to

October 5, 2007.

[27] Bayraktar E, Moiron J, Kaplan D. Effect of welding conditions on the formability characteristics of thin sheet steels: Mechanical and metallurgical effects. J Mater Process Technol 2006; 175: 20-26.

[28] Lakshminarayanan AK, Shanmugam K. Effect of autogenous arc welding processes on tensile and impact properties of ferritic stainless steel joints. Journal of iron and steel research 2009; 16: 62-68.

[29] Taban E, Deleu E, Dhooge A, Kaluc E. Laser welding of modified 12\% Cr stainless steel: Strength, fatigue, toughness, microstructure and corrosion properties. Mater Des 2009; 30: 1193-1200.

[30] Flemings MC. Solidification processing. Metall Trans 1974; 5: 2121-2134.

[31] Greer AL et al. Grain refinement of aluminium alloys by inoculation. Advanced Engineering Material 2003; 5: 81-91.

[32] Kim JC, Kim JJ, Choi JY, Choi JH, Kim SK. Control of columnar-to-equiaxed transition in continuous casting of 16\% Cr stainless steel. La Metallurgia Italiana; sept. 2009: 43-48.

[33] Willers B, Eckert S, Michel U, Haase I, Zouhar G. The columnar-to-equiaxed transition in $\mathrm{Pb}-\mathrm{Sn}$ alloys affected by electromagnetically driven convection. Mater $\mathrm{Sc}$ Engineer 2005; A402: 55-65.

[34] Villafuerte J, Kerr H. Grain structures in gas tungsten-arc welds of austenitic stainless steels with ferrite primary phase. Metall Mater Trans 1990; A21: 979-986.

[35] Villafuerte JC, Kerr HW, David SA. Mechanisms of equiaxed grain formation in ferritic stainless steel gas tungsten arc welds. Mater Sc Engineer 1995; A194: 187-191.

[36] Ostrowski A, Langer EW. Precipitation of titanium carbonitrides in as cast $17 \%$ chromium stainless steels. Scandinavian Journal of Metallurgy 1979; 8: 153-160.

[37] Mallaiah G, Kumar A, Ravinderreddy P, Madhusudhanreddy G. Influence of grain refining elements on mechanical properties of AISI 430 ferritic stainless steel weldments taguchi approach. Mater Des 2012; 36: 443-450.

[38] Amuda MOH, Mridha S. Comparative evaluation of grain refinement in AISI 430 FSS welds by elemental metal powder addition and cryogenic cooling. Mater Des 2012; 35: 609618.

[39] Villaret V, Deschaux-Beaume F, Bordreuil C, Rouquette S, Chovet C. Influence of filler wire composition on weld microstructures of a 444 ferritic stainless steel grade. J Mater Sc Process Technol, in press, DOI: 10.1016/j.jmatprotec.2013.03.026, available online. 
[40] Corrosion of metals and alloys - Test method for isothermal-exposure oxidation testing under high-temperature corrosion conditions for metallic materials. ISO 21608: 2012

[41] Metallic materials - Tensile testing - Part $2:$ method of test at elevated temperature. EN ISO 6892-2: 2011.

[42] Evans UR. The corrosion and oxidation of metals. Edward Arnold Publishers LTD, London, 1960.

[43] Mougin J, Dupeux M, Antoni L, Galerie A. Adhesion of thermal oxide scales grown on ferritic stainless steels measured using the inverted blister test. Mater Sc Engineer 2003;

A359: 44-51.

[44] Bucher L. Etude de l'endommagement en fatigue thermique des aciers inoxydables F17Tnb et R20-12 pour application automobile. PhD thesis, Ecole Nationale Supérieure des Mines de Paris, 2004. in French.

[45] Faivre L, Santacreu PO, Leseux J. Thermal fatigue resistance of MIG/MAG \& laser welded joints in stainless steel exhaust manifolds. 65th ABM Annual Congress, Rio de Janeiro, Brazil. 26-30 July 2010. 
Table 1

Composition of K44X grade.

\begin{tabular}{llllllll}
\hline Element & $\mathrm{C}$ & $\mathrm{Mn}$ & $\mathrm{Si}$ & $\mathrm{Cr}$ & $\mathrm{Mo}$ & $\mathrm{Nb}$ & $\mathrm{N}$ \\
\hline Weight \% & 0.015 & 0.3 & 0.6 & 19.0 & 1.9 & 0.6 & 0.015 \\
\hline
\end{tabular}

Table 2

Welding parameters.

\begin{tabular}{cccc}
\hline $\begin{array}{c}\text { Transfer } \\
\text { mode }\end{array}$ & $\begin{array}{c}\text { Electric power } \\
{[\mathrm{W}]}\end{array}$ & $\begin{array}{c}\text { Welding speed } \\
{\left[\mathrm{cm} \cdot \mathrm{min}^{-1}\right]}\end{array}$ & $\begin{array}{c}\text { Linear welding energy } \\
{\left[\mathrm{J} . \mathrm{cm}^{-1}\right]}\end{array}$ \\
\hline Pulsed & $2540-2675$ & 68 & $2180-2290$ \\
\hline
\end{tabular}

Table 3

Chemical compositions of the foil and of the filler wires developed for the study (weight \%).

\begin{tabular}{|c|c|c|c|c|c|c|c|c|c|c|c|}
\hline Element & $\mathrm{C}$ & $\mathrm{Si}$ & $\mathrm{Mn}$ & $\mathrm{N}$ & $\mathrm{Cr}$ & $\mathrm{Cu}$ & V & $\mathrm{Ni}$ & Mo & $\mathrm{Ti}$ & $\mathrm{Nb}$ \\
\hline Foil & 0.017 & & & & 11.5 & & & & 0.023 & 0.18 & 0.009 \\
\hline FW 2 & \multirow{7}{*}{0.01} & \multirow{7}{*}{0.6} & \multirow{7}{*}{0.3} & \multirow{7}{*}{0.01} & \multirow{7}{*}{19} & \multirow{7}{*}{$<0.3$} & \multirow{7}{*}{0.1} & \multirow{7}{*}{$<0.25$} & \multirow{7}{*}{1.9} & $<0.1$ & 0 \\
\hline FW 3 & & & & & & & & & & 0.45 & 0 \\
\hline FW 4 & & & & & & & & & & $<0.1$ & 0.5 \\
\hline FW 5 & & & & & & & & & & $<0.1$ & 0.8 \\
\hline FW 6 & & & & & & & & & & 0.2 & 0 \\
\hline FW 7 & & & & & & & & & & 0.1 & 0.4 \\
\hline FW 8 & & & & & & & & & & 0.3 & 0.3 \\
\hline
\end{tabular}

\section{Table 4}

Composition of the fusion zones (FZ) obtained with the various filler wires.

\begin{tabular}{cccccccccccc}
\hline Element & $\mathrm{C}$ & $\mathrm{Si}$ & $\mathrm{Mn}$ & $\mathrm{N}$ & $\mathrm{Cr}$ & $\mathrm{Cu}$ & $\mathrm{V}$ & $\mathrm{Ni}$ & $\mathrm{Mo}$ & $\mathrm{Ti}$ & $\mathrm{Nb}$ \\
\hline FZ 2 & - & 0.63 & 0.38 & - & 19.4 & 0.062 & 0.093 & 0.057 & - & 0.045 & 0.21 \\
\hline FZ 3 & 0.030 & 0.60 & 0.35 & 0.0190 & - & 0.052 & 0.086 & 0.055 & 1.95 & 0.26 & 0.23 \\
\hline FZ 4 & 0.037 & 0.52 & 0.32 & 0.0205 & - & 0.058 & 0.070 & 0.061 & - & 0.067 & 0.68 \\
\hline FZ 5 & 0.032 & 0.59 & 0.34 & 0.0202 & 19.4 & 0.066 & 0.075 & 0.068 & - & 0.050 & 0.71 \\
\hline FZ 6 & 0.036 & 0.61 & 0.32 & 0.0210 & - & 0.072 & 0.064 & - & 1.86 & 0.097 & 0.33 \\
\hline FZ 7 & 0.036 & 0.52 & 0.30 & 0.0202 & - & 0.057 & 0.068 & 0.054 & - & 0.051 & 0.53 \\
\hline FZ 8 & 0.037 & - & 0.33 & 0.0231 & - & 0.074 & 0.057 & - & - & 0.15 & 0.44 \\
\hline
\end{tabular}


Table 5

Number of cycles to failure during thermal fatigue tests.

\begin{tabular}{|c|c|c|}
\hline & Sample & Number of cycle to failure \\
\hline \multirow{3}{*}{ Base Metal } & 1 & 9886 \\
\cline { 2 - 3 } & 2 & 9921 \\
\cline { 2 - 3 } & average & 9904 \\
\hline \multirow{4}{*}{ WS 7 } & 1 & 7563 \\
\cline { 2 - 3 } & 2 & 10047 \\
\cline { 2 - 3 } & 3 & 7486 \\
\cline { 2 - 3 } & average & 8365 \\
\hline \multirow{4}{*}{ WS 8 } & 1 & 8189 \\
\cline { 2 - 3 } & 2 & 8620 \\
\cline { 2 - 3 } & 3 & 9916 \\
\cline { 2 - 3 } & average & 8908 \\
\hline
\end{tabular}




\section{Figures}

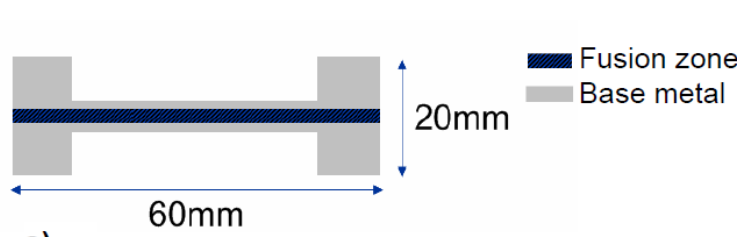

a)

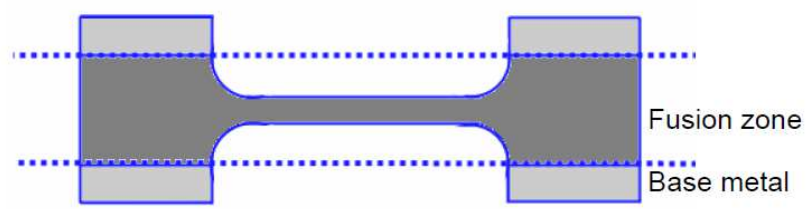

b)

Fig. 1. (a) Geometry of oxidation samples, (b) Geometry of tensile test samples for the characterization of fusion zones.
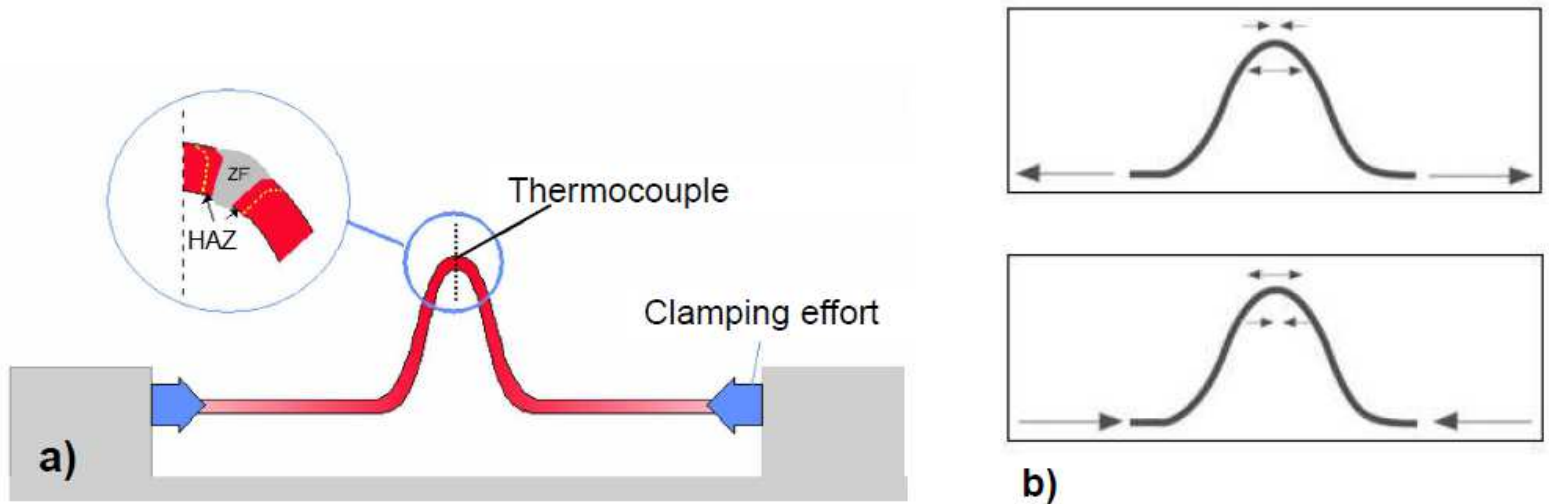

b)

Fig. 2. (a) Geometry of thermal fatigue test samples, (b) loading of the fatigue sample during cooling (up) and heating (down).
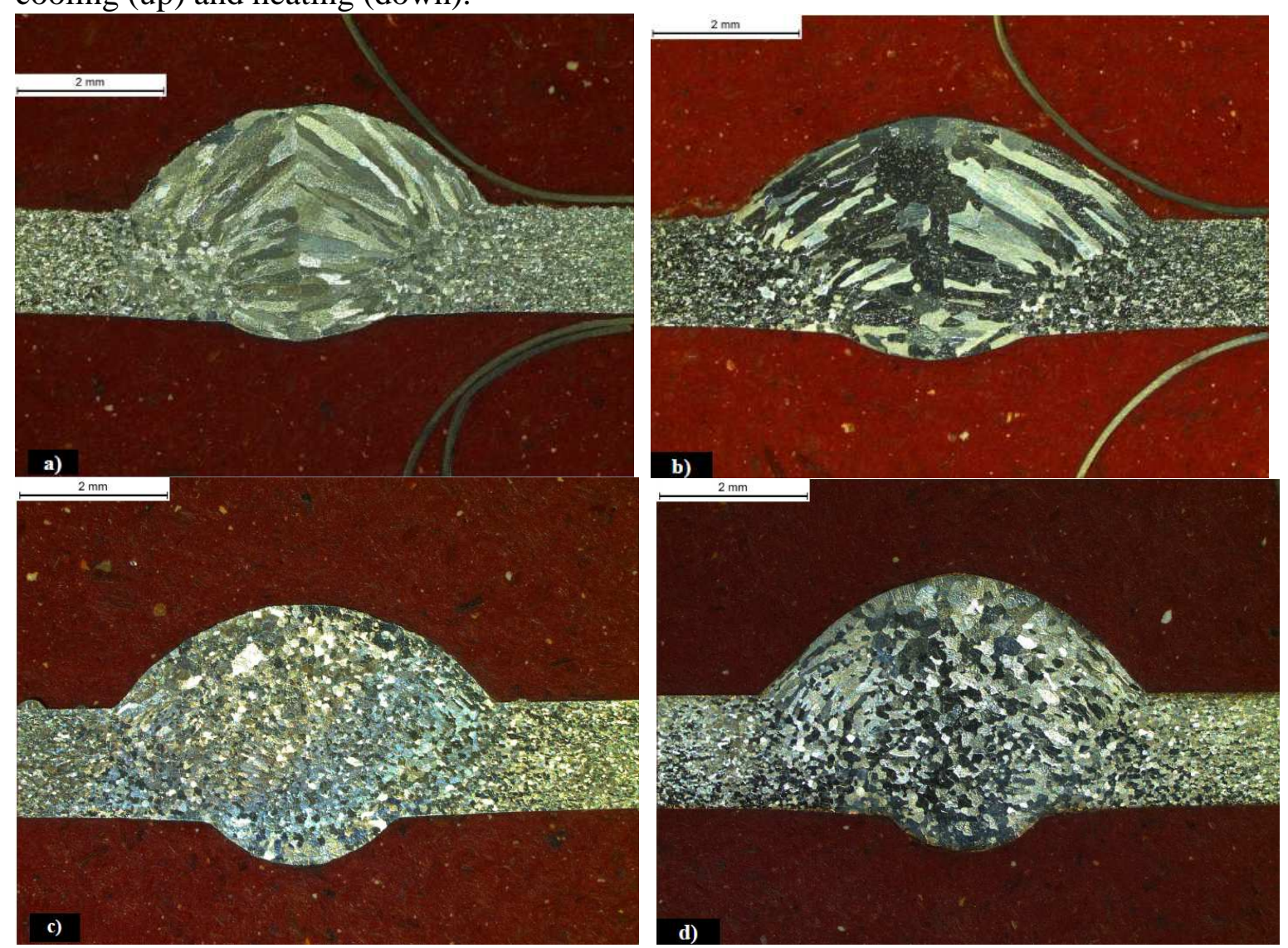

Fig. 3. Influence of Ti content on the grain structure in the fusion zone, (a) $0.05 \%$, (b) $0.10 \%$, (c) $0.15 \%$, (d) $0.25 \%$. 


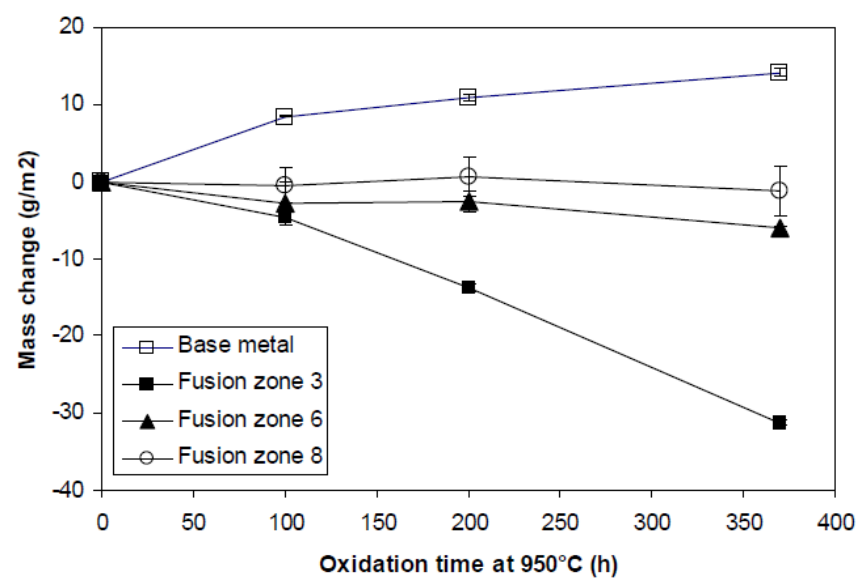

Fig. 4. Evolution of the mass change during isothermal oxidation at $950^{\circ} \mathrm{C}$ before conditioning treatment.
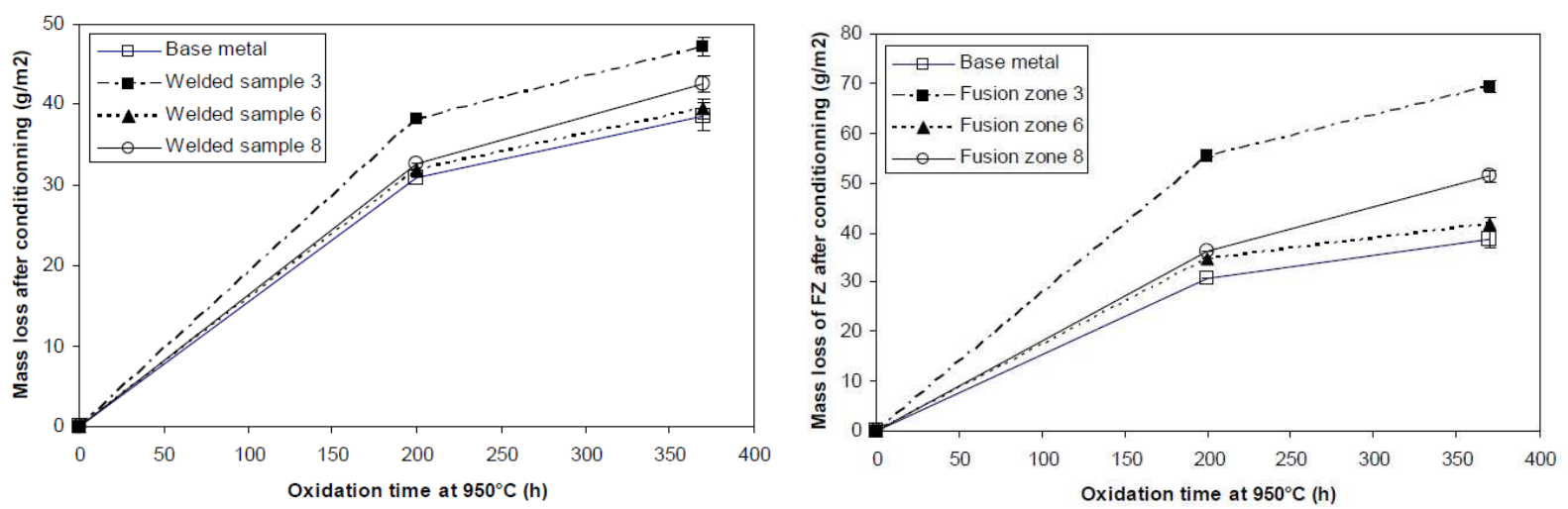

Fig. 5. Evolution of the mass loss during isothermal oxidation at $950^{\circ} \mathrm{C}$ after conditioning treatment, (a) raw values giving the average mass loss on welded samples, (b) treated values indicating the mass loss of the fusion zones only.

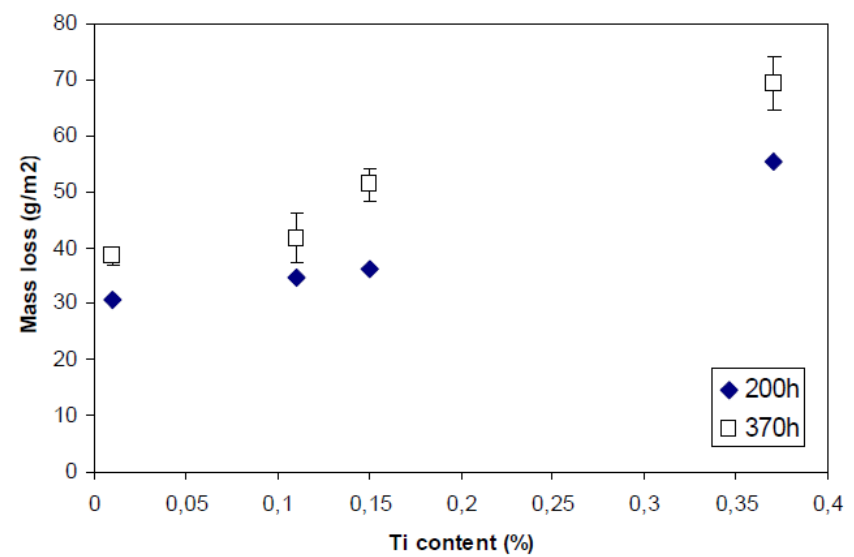

Fig. 6. Evolution of the mass loss during isothermal oxidation tests at $950^{\circ} \mathrm{C}$ versus $\mathrm{Ti}$ content. 

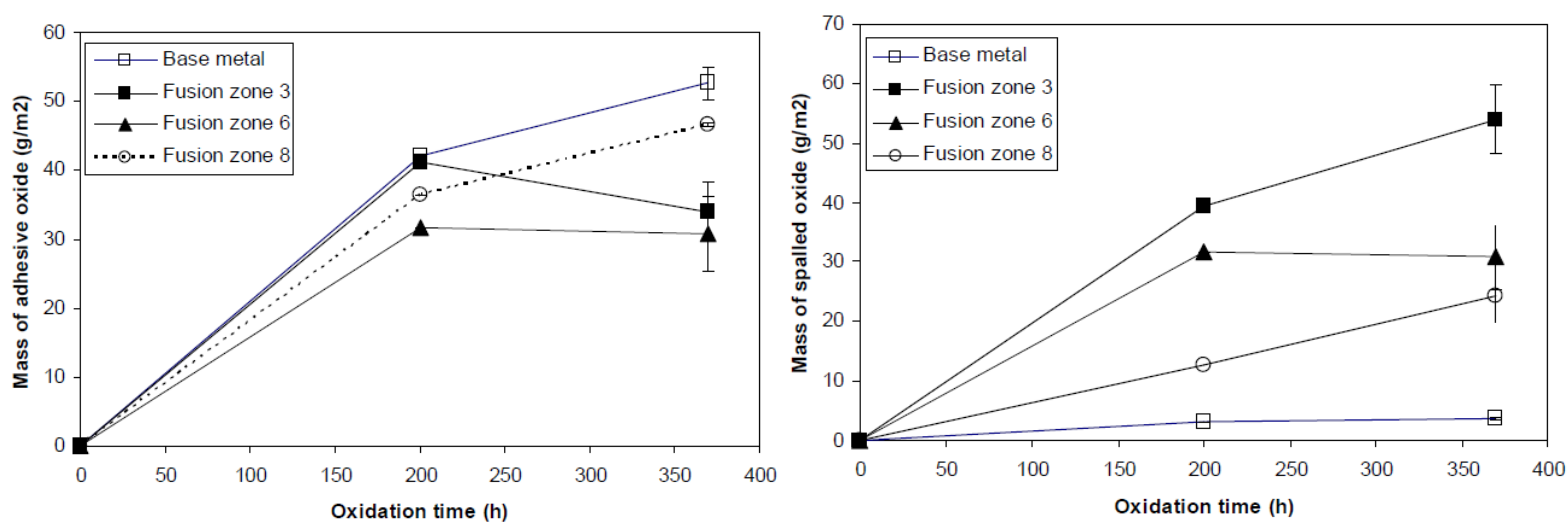

Fig. 7. Evolution of the mass of (a) adhesive oxide and (b) spalled oxide during isothermal oxidation at $950^{\circ} \mathrm{C}$.

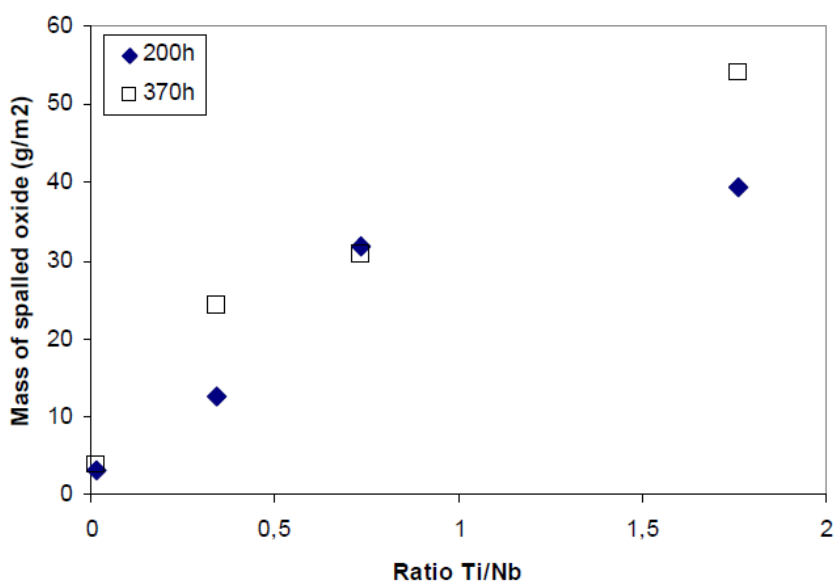

Fig. 8. Evolution of mass of spalled oxide during isothermal oxidation at $950^{\circ} \mathrm{C}$ versus the $\mathrm{Ti} / \mathrm{Nb}$ ratio.

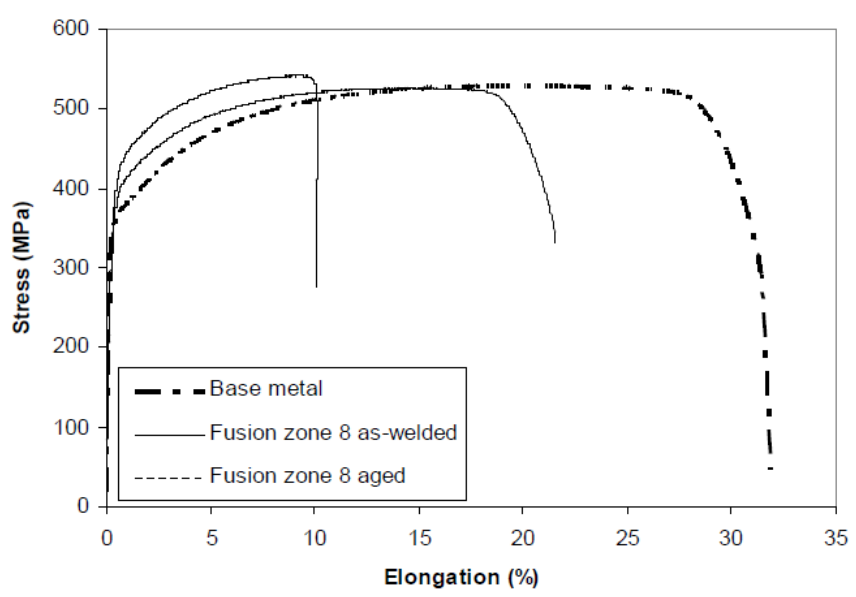

Fig. 9. Room temperature tensile behavior of the base metal and of the fusion zone 8 . 


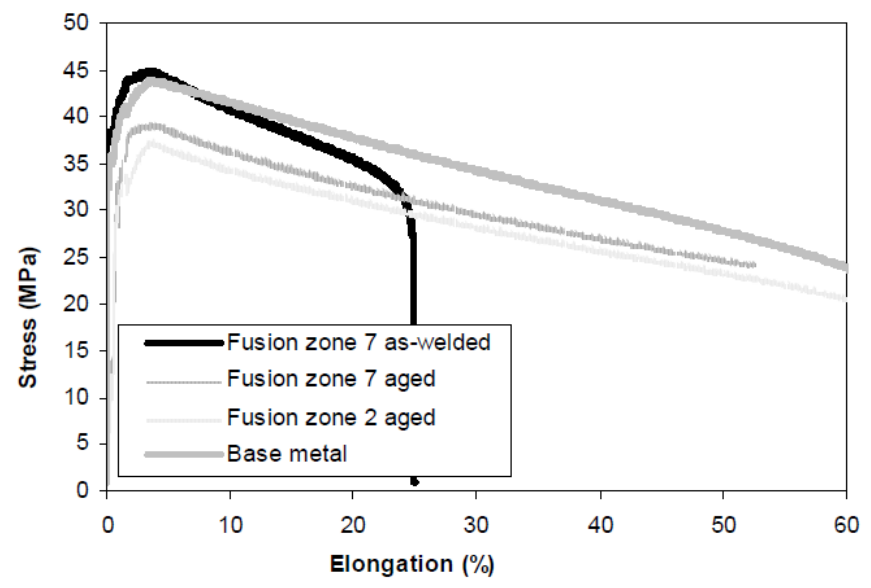

Fig. 10. Tensile behavior of the base metal and of fusion zones at $850^{\circ} \mathrm{C}$.

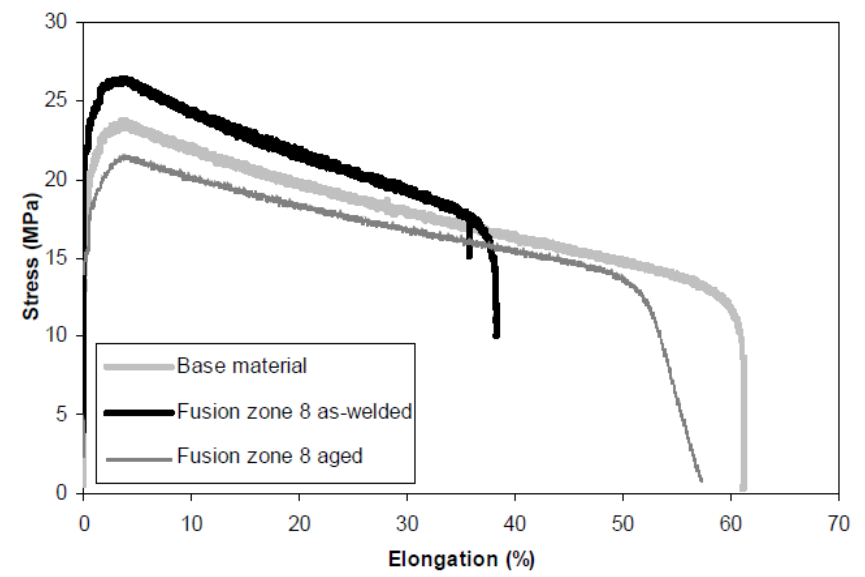

Fig. 11. Tensile behavior of the base metal and of fusion zone 8 at $950^{\circ} \mathrm{C}$.

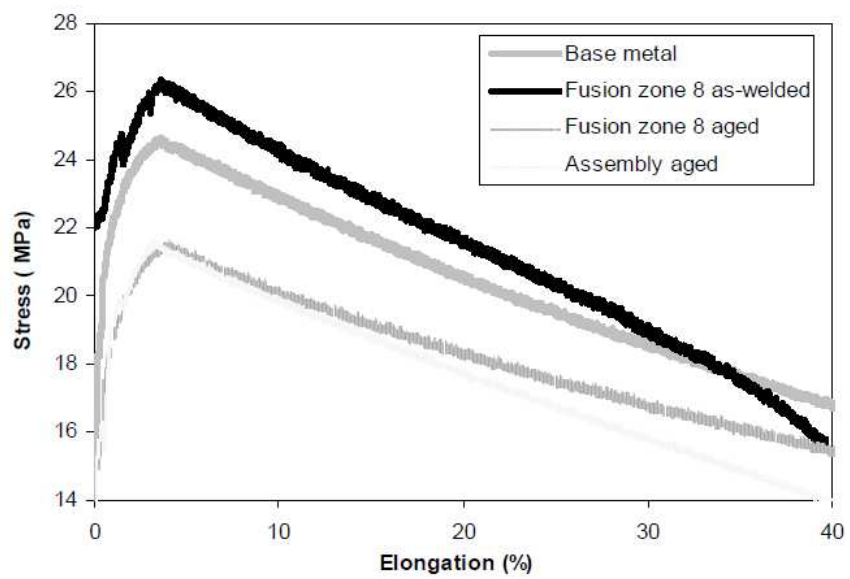

Fig. 12. Comparison of tensile behaviors of the base metal, fusion zone 8 and welded samples at $950^{\circ} \mathrm{C}$.

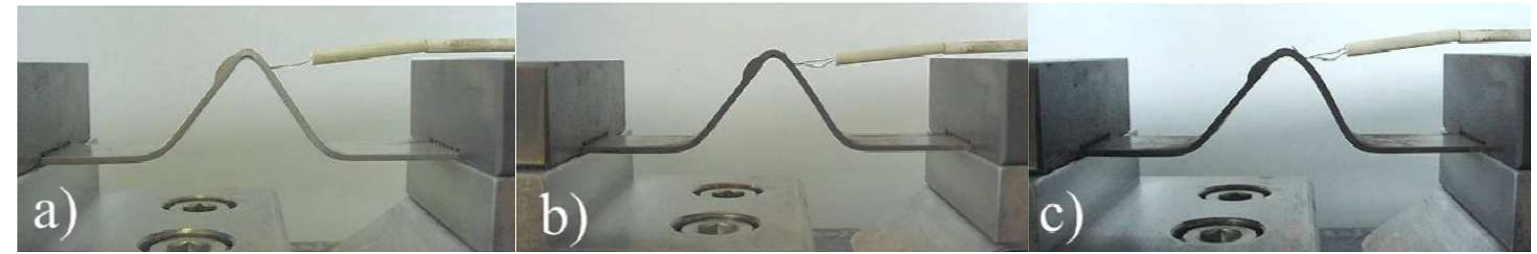

Fig. 13. Evolution of the specimen geometry during thermal fatigue tests on welded sample 8, (a) before testing, (b) after 2000 cycles, (c) at the end of the test. 


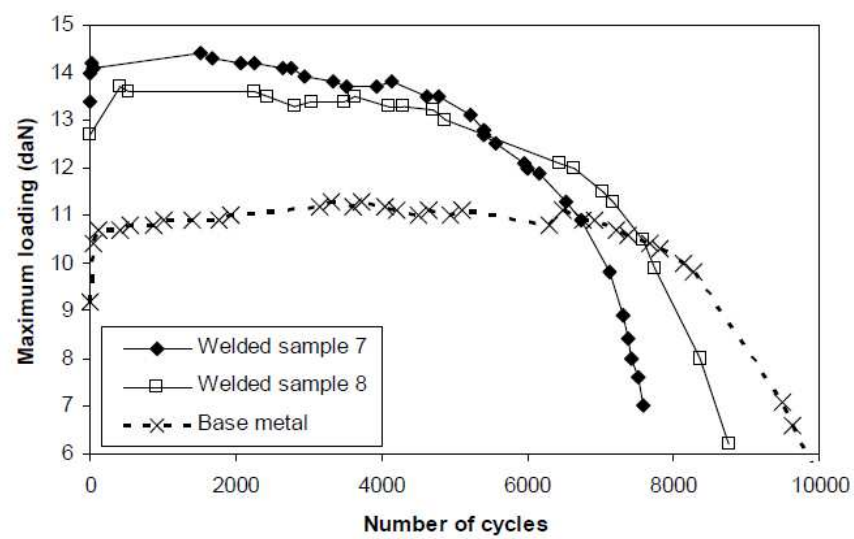

Fig. 14. Evolution of the maximum effort versus the number of cycles during thermal fatigue tests.

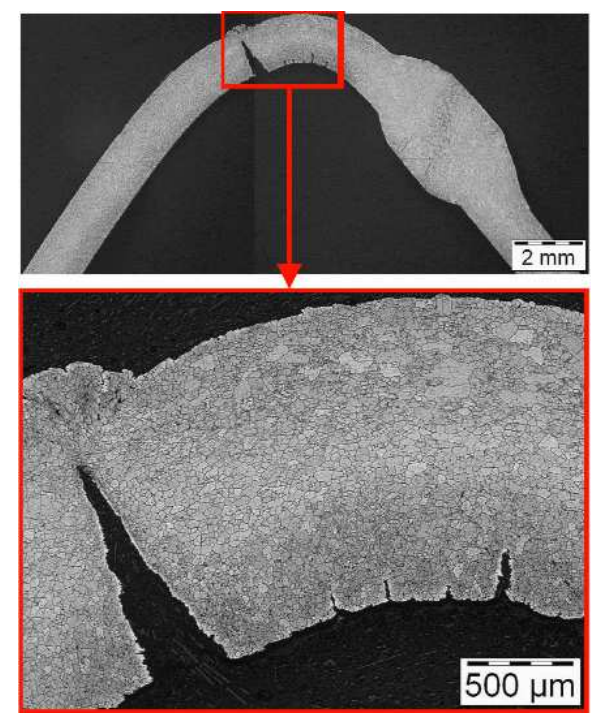

Fig. 15. Crack location during thermal fatigue tests on welded samples. 